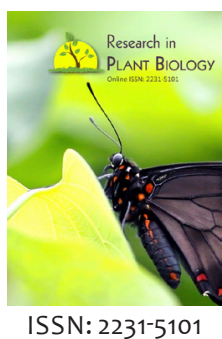

Received: August 10, 2021 Revised: December 30, 2021 Accepted: January 04, 2022 Published: February 22, 2022

*Corresponding Author: Bokary Allaye Kelly

E-mail: bokarykelly@gmail.com

\section{Leaf and fruit characteristics of Parkia biglobosa (Jacq.) Benth according to agro climatic zones and land use in Southern Mali}

\author{
Bokary Allaye Kelly*, Amadou Malé Kouyaté2, Sidiki Gabriel Dembélé3 \\ 'Institut d'Economie Rurale, Programme Ressources Forestières, Centre Régional de la Recherche Agronomique de \\ Sikasso, BP 16 Sikasso, Mali, 'Institut d'Economie Rurale, Centre Régional de la Recherche Agronomique de Sotuba, \\ Bamako, Mali, 3nnstitut Polytechnique Rural de Formation et de Recherche Appliquée (IPR/IFRA) de Katibougou, \\ Koulikoro, Mali
}

\begin{abstract}
A study was conducted in Southern Mali to characterized Parkia biglobosa populations in the aim to contribute to the domestication of the species. Fields and fallows in the North Sudanian, south Sudanian and North Guinean zones were concerned. Adult trees were marked in plots of 0.25 ha each and leaves and fruits were harvested from each tree for characterization. Petiole and laminar length, number of pairs of pinnae and leaflets, pedicel and pod length, pod wide, pod and seed weight, number of seed per pod were measured. The North Guinean zone showed the highest number of pairs of pinnae and leaflets, the longest pods $(23.06 \pm 9.91 \mathrm{~cm}$ in the fields), the highest mean seed weight $(3.74 \pm 0.96 \mathrm{~g}$ in the fields) and the highest mean number of seeds per pod ( $17 \pm 3$ seeds in the fields). The South Sudanian zone showed the longest pedicels $(3.85 \pm 1.08 \mathrm{~cm}$ in the fallows), the highest mean laminar length $(18.02 \mathrm{~cm})$ and mean petiole length $(6.45 \mathrm{~cm})$ in the fields but the same mean number of seeds per pod as for the North Guinean. The North Sudanian zone showed the widest $(17.88 \pm 7.98 \mathrm{~cm}$ in the fields and $18.24 \pm 2.11 \mathrm{~cm}$ in the fallows) and heaviest ( $14.87 \pm 3.95 \mathrm{~g}$ in the fallows) pods. Leaf variables like the number of pairs of pinnae and leaflets seem to be influenced by the climatic gradient. The others leaf, pod and seed variables seem not to be influenced by the climatic gradient. These findings suggest that many leaf and fruit variables are controlled by endogenous factor that could be genetic. However, the manifestation of the endogenous factor seems to be influenced by factors such as environment and management practices.
\end{abstract}

KEYWORDS: Domestication, Fallow, Field, Management practices, Morphological descriptors

\section{INTRODUCTION}

Forest tree species are under high human pressure in degrading ecosystems as observed in recent decades. The drastic decline in crop production and the loss of genetic diversity are the real risks to be observed in the long term (Ouinsavi \& Sokpon, 2010). In the context of climate change, trees could express new potentialities in response to bioclimatic factors (Dicko et al., 2019). Consequently, studies on the ecological adaptation of fruit trees along the climatic gradient are important for predicting their productivity in the future (Glèlè et al., 2011). Tree species are characterized by high genetic diversity linked to geographical origin and to the difference between individuals within the same population (Goba et al., 2019). The diversity is important for adaption of species to various climatic and environmental conditions. Within climatic zones, environmental conditions are known to induce a large spatial variability in the morphology and productivity of fruit trees (Arbonier, 2002) and environmental conditions can cause significant variations in the morphological characteristics of species populations (Dicko et al., 2019). Hence, variability studies are needed to increase plant productivity and also for future breeding work (Freigoun et al., 2017).

The diversity within a species can be assessed through morphological and molecular traits (Ikabanga et al., 2017; Avana-Tientcheu et al., 2019). Phenotypic variability of a species could be assessed by identifying morphological descriptors and morphological data from geographical origins have been used in first studies of genetic diversity of tree species (Kouonon et al., 2020). According to Samim et al. (2018), morphological descriptors are the basis for the characterization of plant genotypes on the basis of their phenotype.

Copyright: $\odot$ The authors. This article is open access and licensed under the terms of the Creative Commons Attribution License (http://creativecommons.org/licenses/by/4.0/) which permits unrestricted, use, distribution and reproduction in any medium, or format for any purpose, even commercially provided the work is properly cited. Attribution - You must give appropriate credit, provide a link to the license, and indicate if changes were made. 
Many studies had concerned the variability of species showing great interest to the local populations. Studies addressing morphological variability of species have concerned: Adansonia digitata in Mali and Benin (Assogbadjo, 2006; Kouyaté et al., 2011), Argania spinosa in the South-West Morocco (Zahidi et al., 2013), Sclerocarya birrea in Benin and in Burkina Faso (Bationo, 2008; Gouwakinnou, 2011), Prosopis africana in Benin (Houètchegnon et al., 2015), Vitellaria paradoxa in Mali (Kelly \& Senou, 2017). Recent studies have been focused on the variability of morphological traits and to the identification of morphological descriptors of several tree species like Adansonia digitata (Bamba et al., 2019), Lophira lanceolata (Dicko et al., 2019; Lankoande et al., 2020), Pterocarpus erinaceus (Johnson et al., 2020), Parkia biglobosa (Avana-Tientcheu et al., 2019; Kouonon et al., 2020).

Parkia biglobosa is a forest tree species of the family of Leguminosae/ Fabaceae (Sancandé et al., 2016), common in agroforestry parklands in the Sudanian zone. Ayihouenou et al. (2016) reported that its conservation and domestication for the diversification of agricultural production depend on its ability to adapt to climate change. Lompo et al. (2017) reported that, a sound conservation strategy for P. biglobosa and the promotion of its sustainable management should be based on scientific information about threats as well as ecological and genetic processes affecting this species. Assessment of the variation of the morphological traits of this species in relation to agro-climatic zones could contribute to this scientific information needed for a successful conservation strategy. Also, it is essential to know the phenotypical variability of this species for domestication purposes so that to preserve goods and services provided by P. biglobosa (Kouonon et al., 2020).

In Mali, P. biglobosa is one of the most important parkland tree species, present in the north and the south of Sudanian zones in the regions of Kayes, Koulikoro, Ségou, Sikasso and in the North Guinean zones in the regions of Kayes and Sikasso (Fagui, 2015). It is a forest tree species which regenerates naturally. The cultivation of P. bigolobsa began only recently and it is still very limited. Nursery experiments for seedlings production and on-field plantation experiments started in Mali in the 1990's.

P. biglobosa is a multi-purpose tree species having almost the same uses in the three study sites. The species provides food for human beings (e.g., pulp and grains used to produce the spice called "soumbala" or "dawadawa"). This spice is rich in proteins and contains lipids, essential amino acids, essential fatty acids, vitamins and mineral compounds (Ouoba et al., 2003). It is particularly appreciated and widely used in Africa. P. biglobosa provides food for animals also (pulp) and contributes to generate income for rural populations. Therefore, the species contributes fighting poverty. It provides medicine and sometimes craft wood (mainly in the north and south Sudanian zones).

Populations of this species are highly threatened in large parts of its range due to over-exploitation and environmental degradation (Lompo et al., 2017). Nowadays, the density of P. biglobosa trees is very low in farmed fields as well as in the fallows. The low density could be explained by several causes like natural mortality, density reduction by farmers in the field to reduce competition with associated crops (mainly cash crops like cotton which was in expansion in the whole Southern Mali) and the weak natural regeneration in the fallow. These constraints in addition to climate change could lead, in the adaptation strategies of the species, to a variability of leaf and fruit characteristics, which is important to assess. Lompo et al. (2017) reported that, in the light of climatic changes, safeguarding the genetic diversity of the species is crucial to foster adaptation and to support its long-term survival.

The objective of the study was to contribute to the domestication of the species in Mali. More specifically, it aimed (i) to assess the variability of leaf and fruit characteristics according to land use and agro-climatic zones along the North-South climatic gradient, (ii) to identify morphological descriptors important for the resilience of the species.

\section{MATERIAL AND METHODS}

\section{Study sites}

The study was conducted in three agro-climatic zones (the North Sudanian NS, the South Sudanian SS, and the North Guinean NG). These zones were selected based on climatic and environmental conditions as well as management practices (land use and tree management systems). In the NS zone, the mean annual rainfall varies from 500 to $800 \mathrm{~mm}$. It is a zone of slightly undulated plains, lowlands and depressions with heavy soils quite wet, and actively cultivated. It also contains extensive, fine-textured plains. The natural vegetation is constantly being degraded, and the existing woody species are those spared by man. In the SS zone, the mean annual rainfall varies from 800 to $1100 \mathrm{~mm}$. Soils are deep alluvial, often the most fertile in the country, used for continuous cultivation and short fallow systems. The soils on rocky foundations are shallow or moderately deep. There are open or moderately dense woody stands on shallow soils. In the NG zone, the rainfall is over $1100 \mathrm{~mm}$ per year. The valleys in this area are cultivated in a continuous regime. Fallow system is longer and the density of woody species is higher. It is an excellent zone of timber exploitation. It is important to notice that the average altitude of parcels of studied populations of P. biglobosa increased from north to south but the difference in altitude was not very substantial. These altitudes in average were $276 \mathrm{~m}$ in NS zone, $312 \mathrm{~m}$ in the SS zone and $332 \mathrm{~m}$ in the NG zone.

Land and parkland trees are managed differently in the study sites. In the NG zone, land is less scarce and shifting cultivation still exists whereas in the other two zones, due to land scarcity, the same parcels are used continuously or with short fallow period. P. biglobosa is 432 officially protected by national legislation in Mali. Despite this protection, the species is cut for various purposes according to zones. In the NG zone, vegetation is relatively abundant and P. biglobosa trees are less exploited for purposes like fuel wood, charcoal or craft wood in contrary to the Sudanian zones, where cases of P. biglobosa exploitation were observed. Hence, P. biglobosa tree densities in the Sudanian zones are lower compare to the NG zone and because of the 
use of the same parcels continuously, P. biglobosa trees are older and bigger. They are often pruned to favour associated crops.

In each zone, one site was selected based on the availability of $P$. biglobosa populations in fields and fallows, the accessibility in all seasons, and the willingness of farmers to collaborate in research activities. Selected sites were Somasso (district of Bla) in the NS zone, Zanzoni (district of Koutiala) in the SS zone and Diou (district of Kadiolo) in the NG zone. Figure 1 shows the localization of the three study zones within southern Mali and Figure 2 shows the localization of the sites within the respective districts.

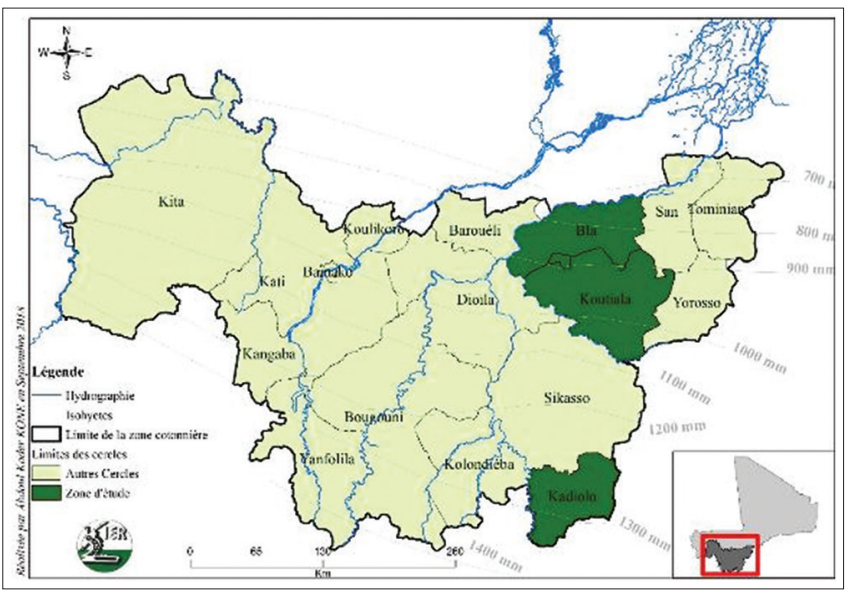

Figure 1: Localization of study zones (green areas) within southern Mali
The site of Somasso $\left(51^{\circ} 31^{\prime} \mathrm{N}, 36^{\circ} 27^{\prime} \mathrm{W}\right)$ in the NS zone, has a little uneven relief composed of cultivable plains. The climate is north Sudanian, characterized by two seasons (the long dry season from October to May and the short rainy season from June to September). Agriculture is the main activity and the cultivated areas are large, dominated by cereal crops. Cotton and groundnuts are the cash crops. Vegetation is shrubby savannah with some big trees spared in the fields such as Parkia biglobosa, Vitellaria paradoxa, Faidherbia albida (PDESC, 2019). The site of Zanzoni $\left(36^{\circ} 52^{\prime} \mathrm{N}, 32^{\circ} 05^{\prime} \mathrm{W}\right)$ in the SS zone, has little hilly relief composed of plains favourable for off-season crops. The climate is south Sudanian, with also two seasons with length similar to those of the site of Somasso. Agriculture concerns cereals production and cash crops such as cotton and peanuts. Vegetal resources are similar to those of the site of Somasso but, some protected forests and sacred woods are present (PDESC, 2019). The site of Diou (3546’N, 58³3’W) in the NG zone, has a slightly uneven relief. The climate is North Guinean, with a dry season from November to May and a rainy season from May to October. Agriculture is the main activity and cereal production is mainly composed of Maize, while Cotton is grown as a cash crop. There are important natural stands of forest resources, artificial plantations of exotic species and sacred woods (PDESC, 2017).

\section{Study design}

The study design consisted of square plots of $50 \mathrm{~m} \times 50 \mathrm{~m}=2500 \mathrm{~m}^{2}(0.25 \mathrm{ha})$. Two factors were studied:

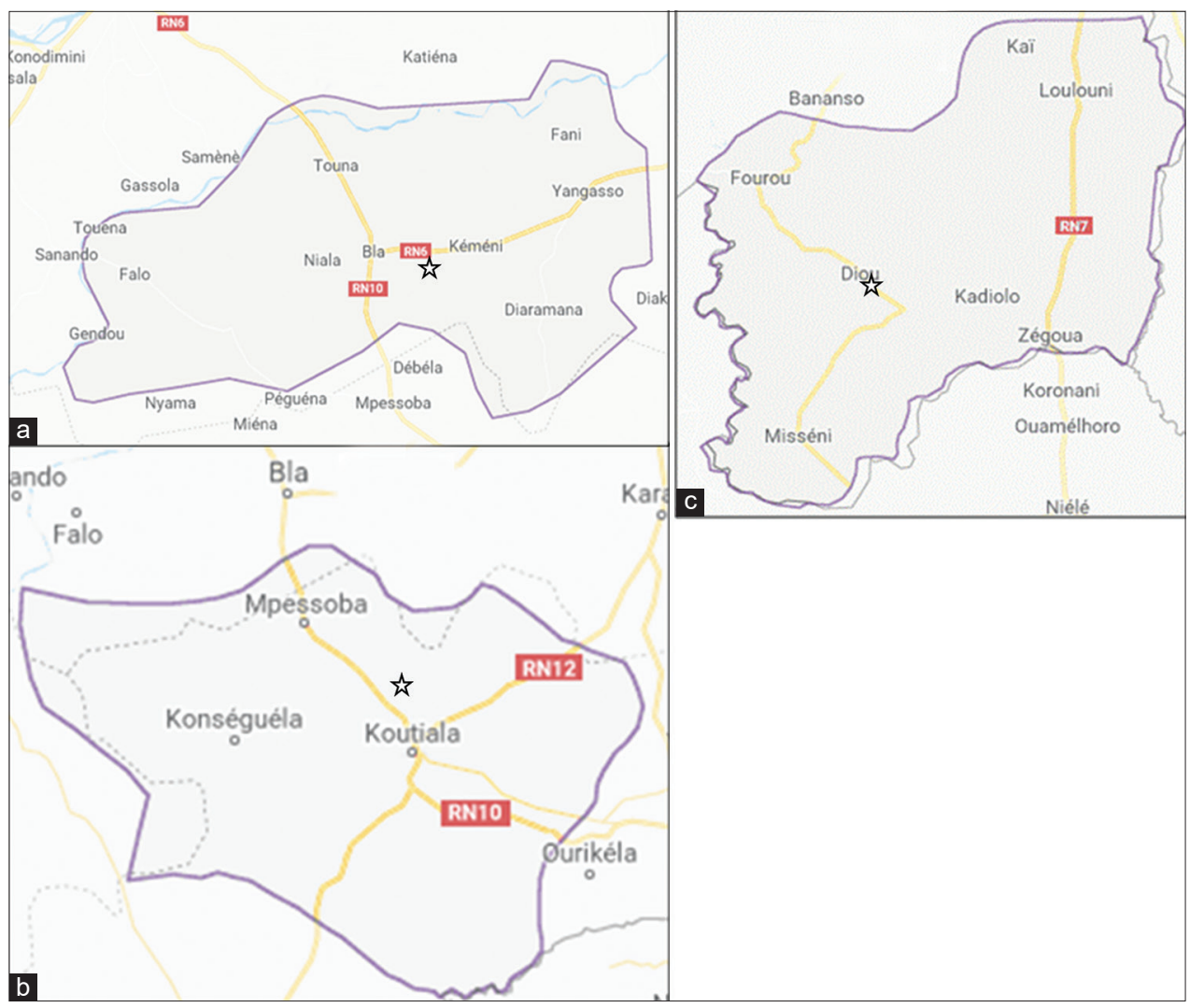

Figure 2: Localization of selected sites within the respective districts, each indicated by a star (2a Somasso in the district of Bla, 2b Zanzoni in the district of Koutiala and 2c Diou in the district of Kadiolo) 
the factor agro-climatic zones (ACZ) with three levels (NS, SS and NG) and the factor land use "called stand in the paper" with two levels (fields and fallows). Three plots were installed in each stand within each zone giving six plots per agroclimatic zone. A total of eighty (18) populations (6 plots x 3 agro-climatic zones) of $P$. biglobosa was concerned. All adult $P$. biglobosa trees $(\mathrm{DBH} \geq 10 \mathrm{~cm})$ in the plots were marked and measured. Geographical position of each tree was recorded using a GARMIN eTrex 10 GPS (accuracy $\pm 3 \mathrm{~m}$ ).

\section{Data collection and analysis}

Fruits and leaves were harvested from all trees in the plots. For leaf characterization, 50 leaves were sampled per tree. Laminar and petiole length was measured, the number of pairs of pinnae (NPP) was counted as well as the number of pairs of leaflets (NPLt) of the pinnae at the basis, at the middle and at the top of the laminar. For fruit characterization, 50 pods were harvested from trees having sufficiently fruited. Pods weight (PoWe) was determined using electronic balance AND GR 202 (precision $\pm 0,1 \mathrm{mg}$ ), pod length (PodL) and pedicel length (PediL) were measured using ruler and their width (PodWi) was measured using Vernier calliper SUNRISE (precision $\pm 0,02 \mathrm{~mm}$ ). After pulp removal, the number of seeds per pod (Nseeds) was counted and fresh seeds weight (SeedWe) was determined using electronic balance.

Descriptive statistics were computed. The correlations of leaf variables with each other and with dendrometric parameters of the trees were assessed. The same assessment was done for fruit variables. Analysis of variance was used to determine the effect of studied factors at $5 \%$ significance level. For factors whose effects were significant, multiple comparison of the means was made to distinguish the levels of the factor that were significantly different according to Bonferonni's method.

\section{RESULTS}

\section{Summary statistics and correlations}

Statistics for tree and leaf variables were shown in table 1. Some tree variables (DBH, MCD) and some leaf variables (LL, PL) showed a relative high variability.

Correlations matrix between variables were shown in table 2 . Correlations of leaf variables with tree parameters were weak and most of them were negative. Correlations of leaf variables to each other were also weak (Table 2 ). The only relatively high correlation was that between laminar length and the number of pairs of pinnae (0.64). However, high correlations were observed between some tree parameters. DBH was highly and positively correlated with MDC and TH, these last two parameters were also highly and positively correlated (Table 2).

Summary statistics for tree and fruit variables were shown in table 3. Some tree variables (DBH, MCD) and fruit variables (PediL, PodL, PodWe, Nseeds, SeedWe) showed a relatively high variability (Table 3 ).
Table 1: Summary statistics for tree and leaf variables

\begin{tabular}{lccccc}
\hline & Mean & Stand dev. & Cv \% & Mini & Maxi \\
\hline DBH $(\mathrm{cm})$ & 59.23 & 20.12 & 33.97 & 17.00 & 114.00 \\
MCD $(\mathrm{m})$ & 13.24 & 3.65 & 27.57 & 4.42 & 20.25 \\
TH $(\mathrm{m})$ & 11.83 & 2.22 & 18.77 & 4.80 & 16.00 \\
LL $(\mathrm{cm})$ & 17.79 & 4.15 & 23.33 & 4.00 & 40.00 \\
PL $(\mathrm{cm})$ & 6.06 & 1.53 & 25.25 & 2.00 & 16.500 \\
NPP & 10 & 2 & 20.00 & 2 & 17 \\
NPLtBP & 31 & 6 & 19.35 & 7 & 62 \\
NPLtCP & 41 & 6 & 14.63 & 13 & 79 \\
NPLtTP & 32 & 7 & 21.88 & 5 & 60 \\
\hline
\end{tabular}

$\mathrm{DBH}=$ diameter at body height, $\mathrm{MCD}=$ mean crown diameter, $\mathrm{TH}=$ total height, $L L=$ laminar lenght, $P L=$ petiole lenght, $N P P=$ number of pairs of pinnae, NPLtBP=number of pairs of leaflets for pinnae at the basis of the laminar, NPLtCP=number of pairs of leaflets for pinnae at the centre, NPLtTP=number of pairs of leaflets for pinnae at the top

Correlations matrix between variables were shown in table 4 . Correlations of fruit variables with tree parameters were weak and some of them were negative. Correlations of fruit variables to each other were also weak (Table 4). Relatively high correlations were observed between pod length and pod weight (0.79), pod length and seeds weight (0.65), number of seeds and seed weight $(0.72)$, pod weight and seed weight $(0.75)$. Some relatively high correlations were also observed between tree parameters (Table 4). DBH was positively correlated with MDC (0.68) and TH (0.61). These last two parameters were also positively correlated $(0.76)$.

\section{Leaf characteristics of $P$. biglobosa}

The analysis of variance showed a significant effect of ACZ for all the leaf variables $(\mathrm{p}<0.001)$. The effect of stand was also significant for most of variables, but the interaction between the two factors was not significant. The means of measured variables were shown in table 5 .

For leaf size variables, the highest mean laminar length $(18.02 \mathrm{~cm})$ was observed in the SS zone. This zone was not significantly different to the NG zone and both, showed significant higher means compared to the NS zone (Table 5). The highest mean petiole length also was observed in SS zone $(6.45 \mathrm{~cm})$ which was significantly higher than that observed in the NS and NG zones. Fields showed significant higher means for leaf size variables and for the number of pairs of pinnae compared to fallows (Table 5).

For the number of pairs of pinnae and leaflets, the NG zone showed significant higher means compared to the SS and NS zones. These latter were also significantly different for the number of pairs of leaflets for pinnae at the centre and at the top of the laminar, the NS zone showing significant higher means compared to the SS zone (Table 5). Fields and fallows were not significantly different for the number of pairs of leaflets for pinnae at the basis and at the top of the laminar, but they were significantly different for the number of pairs of pinnae (NPP) and for the number of pairs of leaflets at the centre of the laminar (NPLtCP). Fields showed highest mean for NPP, while fallows showed highest mean for NPLtCP. 
Table 2: Correlation matrix for tree and leaf variables

\begin{tabular}{|c|c|c|c|c|c|}
\hline $\mathrm{DBH}$ & 1.000 & & & & \\
\hline MCD & 0.700 & 1.000 & \\
\hline TH & 0.702 & 0.713 & \multicolumn{2}{|c|}{1.000} & \\
\hline LL & -0.007 & -0.094 & \multicolumn{2}{|c|}{0.014} & 1.000 \\
\hline PL & 0.065 & -0.043 & \multicolumn{2}{|c|}{0.027} & 0.363 \\
\hline NPP & -0.242 & -0.195 & \multicolumn{2}{|c|}{-0.179} & 0.639 \\
\hline NLtBP & 0.006 & 0.026 & \multicolumn{2}{|c|}{0.104} & 0.102 \\
\hline NLtCP & -0.033 & 0.019 & \multicolumn{2}{|c|}{0.047} & 0.175 \\
\hline NLtTP & -0.031 & 0.015 & \multicolumn{2}{|c|}{0.063} & 0.088 \\
\hline & DBH & MCD & \multicolumn{2}{|c|}{$\mathrm{TH}$} & $\mathrm{LL}$ \\
\hline \multicolumn{6}{|c|}{$\begin{array}{l}\text { Numbers in bold indicate relative high correlation between variables } D B H \\
L L=\text { laminar lenght, } P L=\text { petiole lenght, } N P P=\text { number of pairs of pinnae, } \\
N P L t C P=\text { number of pairs of leaflets for pinnae at the centre, NPLtTP=n }\end{array}$} \\
\hline \multicolumn{6}{|c|}{ Table 3: Summary statistics for tree and fruit variables } \\
\hline & Mean & Stand dev. & Cv \% & Mini & Maxi \\
\hline$\overline{\mathrm{DBH}}(\mathrm{cm})$ & 62.29 & 18.34 & 29.44 & 31.00 & 105.00 \\
\hline $\operatorname{MCD}(\mathrm{m})$ & 13.89 & 3.10 & 22.32 & 6.65 & 18.45 \\
\hline $\mathrm{TH}(\mathrm{m})$ & 12.24 & 1.79 & 14.60 & 8.55 & 15.00 \\
\hline PediL (cm) & 3.623 & 1.151 & 31.772 & 1.000 & 9.000 \\
\hline PodL (cm) & 20.95 & 4.53 & 21.60 & 4.70 & 35.50 \\
\hline PodWi (mm) & 16.95 & 2.42 & 14.28 & 5.22 & 29.25 \\
\hline PodWe (g) & 13.05 & 3.77 & 28.85 & 2.98 & 27.81 \\
\hline Nseeds (n) & 16 & 4 & 25.68 & 3 & 42 \\
\hline SeedWe (g) & 3.333 & 1.066 & 31.992 & 0.590 & 8.380 \\
\hline
\end{tabular}

$\mathrm{DBH}=$ diameter at body height, $\mathrm{MCD}=$ mean crown diameter, $\mathrm{TH}=$ total height, PediL=pedicel length, $\mathrm{Pod} L=$ pod length, $\mathrm{PodWi}=$ pod wide, PodWe $=$ pod weight, Nseeds $=$ number of seeds, SeedWe = seed weight

\section{Fruit characteristics of $P$. biglobosa}

The analysis of variance showed a significant effect of ACZ for the fruit variables excepted seed weight $(\mathrm{p}=0.303)$. Stand effect was also significant for the fruit variables excepted for pedicel length $(\mathrm{p}=0.264)$. For all fruit variables, a highly significant interaction between site and stand was observed $(\mathrm{p}<0.001)$. The means of fruit size parameters were shown in Table 6.

The longest pedicels were observed in the fallows in the SS zone $(3.85 \pm 1.08 \mathrm{~cm})$. This mean pedicel length was not significantly different than those observed in the fields in the NS and SS zones and in the fallows in the NG zone. The shortest pedicels were observed in the fields in the NG zone which showed the longest pods $(23.06 \pm 9.91 \mathrm{~cm})$, significantly higher than all other observed means for that variable (Table 6). The shortest pods were observed in the fields and fallows in the NS zone which showed the widest pods $(17.88 \pm 7.98 \mathrm{~cm}$ and $18.24 \pm 2.11 \mathrm{~cm}$ respectively), significantly higher than the means observed in the stands of the other two agro-climatic zones (Table 6). The means of pod and seed parameters were shown in table 7.

The heaviest pods were observed in the fallows in the NS $(14.87 \pm 3.95 \mathrm{~g})$, significantly higher than all observed means for that variable (Table 7). The lowest mean pod weight was observed in the fallows in NG zone, while the fields of that zone showed the highest mean seed weight $(3.74 \pm 0.96 \mathrm{~g})$. This mean seed weight was not significantly different than that observed in the fields in the SS zone (Table 7). The highest mean number of seeds per pod (17 \pm 3 seeds) was observed in the fields in

the SS and NG zones. The lowest mean number of seeds per pod $(15 \pm 4)$ was observed in the fields in the NS zone and in the fallows in SS and NG zones (Table 7).

\section{DISCUSSION}

Leaf variables such as NPP, NPLtBP, NPLtCP and NPLtTP seem to be influenced by the climatic gradient. Means of these variables observed in the wettest zone (NG) were higher than those observed in dryer zones (NS and SS). The reduction of the number of organs (pinnae and leaflets) in the dryer zone could be a strategy for adaptation to environmental conditions. Hence, P. biglobosa, to survive in less favorable zone, would reduce the organs that could contribute to the excessive consumption or loss of water by respiration or evapotranspiration. These variables could be considered as morphological descriptors of the species resilience strategies. For leaf size variables (PL, LL) as well as for pod and seed variables, variations according to ACZ did not show a climatic gradient effect. In the majority of cases, means observed in the dryer zones (NS and SS) were higher than those observed in the wettest zone (NG). A similar phenomenon was observed for V. paradoxa in Nigeria by Ugese et al. (2010), in Ghana by Nyarko et al. (2012), in Uganda by Gwali et al. (2012), in Chad by Djekota et al. (2014) and in Mali by Kelly and Senou (2017). This result suggests a possible control of some agro-morphological traits of leaves and fruits by the genetic factor as it was reported for forest tree species in previous studies. For instance, Ouédraogo (1995) reported geographical variation in the provenance of P. biglobosa seeds in SudanoSahelian countries with rainfall below $1200 \mathrm{~mm}$. According to this author, such results imply significant genetic variability in P. biglobosa. Several other studies have demonstrated genetic differences between provenances of same species (Ouédraogo, 1986; Brown \& Hardner, 2000; Ræbild et al., 2003).

Regarding the zone effect, a significant difference was observed between sites for several leaf and fruit variables. Differences between sites for leaf and fruit variables of $P$. biglobosa have been reported by several authors through studies in the sub-region. For instance, Oyerinde et al. (2018) observed a significant difference among 3 sites in southwestern Nigeria for several fruit variables (number of pods, pod weight, pod length and width, and seed weight). Their results showed that, for many variables, the wettest and the dryer sites were not significantly different, which was consistent with our results. These authors believe 
Kelly et al.

Table 4: Correlation matrix for tree and fruit variables

\begin{tabular}{|c|c|c|c|c|c|c|c|c|c|}
\hline DBH & 1.000 & & & & & & & & \\
\hline MCD & 0.684 & 1.000 & & & & & & & \\
\hline PodWi & 0.215 & 0.182 & 1.000 & & & & & & \\
\hline TH & 0.606 & 0.763 & 0.227 & 1.000 & & & & & \\
\hline PodL & 0.058 & 0.058 & 0.276 & 0.053 & 1.000 & & & & \\
\hline PediL & 0.114 & 0.100 & 0.011 & 0.096 & -0.027 & 1.000 & & & \\
\hline Nseeds & -0.055 & 0.049 & 0.091 & -0.009 & 0.549 & -0.051 & 1.000 & & \\
\hline PodWe & 0.128 & 0.178 & 0.520 & 0.172 & 0.786 & -0.032 & 0.554 & 1.000 & \\
\hline SeedWe & $\begin{array}{c}-0.014 \\
\text { DBH }\end{array}$ & $\begin{array}{l}0.069 \\
M C D\end{array}$ & $\begin{array}{l}0.329 \\
\text { PodWi }\end{array}$ & $\begin{array}{c}0.020 \\
\mathrm{TH}\end{array}$ & $\begin{array}{c}0.649 \\
\text { PodL }\end{array}$ & $\begin{array}{c}-0.073 \\
\text { PediL }\end{array}$ & $\begin{array}{c}0.725 \\
\text { Nseeds }\end{array}$ & $\begin{array}{l}0.748 \\
\text { PodWe }\end{array}$ & $\begin{array}{c}1.000 \\
\text { SeedWe }\end{array}$ \\
\hline
\end{tabular}

Numbers in bold indicate relative high correlation between variables $\mathrm{DBH}=$ diameter at body height, $\mathrm{MCD}=$ mean crown diameter, $\mathrm{TH}=$ total height, Pedi $\mathrm{L}=$ pedicel length, $\mathrm{PodL}=$ pod length, $\mathrm{PodWi}=$ pod wide, $\mathrm{PodWe}=$ pod weight, Nseeds $=$ number of seeds, SeedWe $=$ seed weight

Table 5: Mean leaf variables by agro-climatic zones and by stand

\begin{tabular}{|c|c|c|c|c|c|c|}
\hline \\
\hline \multicolumn{7}{|l|}{$\begin{array}{l}\text { Mean leaf variables } \\
\text { ACZ/Stands }\end{array}$} \\
\hline North Sudanian (NS) & $17.39 \pm 4^{b}$ & $5.91 \pm 1^{b}$ & $9 \pm 2^{b}$ & $30 \pm 6^{b}$ & $41 \pm 6^{b}$ & $32 \pm 7^{b}$ \\
\hline South Sudanian (SS) & $18.02 \pm 4^{a}$ & $6.45 \pm 2^{\mathrm{a}}$ & $9 \pm 2^{b}$ & $30 \pm 6^{b}$ & $40 \pm 6^{c}$ & $31 \pm 7^{c}$ \\
\hline North Guinean (NG) & $17.96 \pm 4^{a}$ & $5.81 \pm 1^{b}$ & $11 \pm 2^{\mathrm{a}}$ & $32 \pm 6^{a}$ & $43 \pm 5^{a}$ & $33 \pm 7^{a}$ \\
\hline Fields & $18.17 \pm 4^{a}$ & $6.16 \pm 1^{\mathrm{a}}$ & $10 \pm 2^{\mathrm{a}}$ & $31 \pm 6^{a}$ & $41 \pm 5^{b}$ & $32 \pm 7^{\mathrm{a}}$ \\
\hline Fallows & $17.40 \pm 4^{b}$ & $5.95 \pm 1^{b}$ & $9 \pm 2^{b}$ & $31 \pm 6^{a}$ & $42 \pm 6^{a}$ & $32 \pm 7^{a}$ \\
\hline Avarege (all ACZ and stands) & $17.79 \pm 4$ & $6.06 \pm 1$ & $10.17 \pm 2$ & $31.16 \pm 6$ & $41.84 \pm 6$ & $32.40 \pm 7$ \\
\hline
\end{tabular}

Means with the same letter were not significantly different. $A C Z=$ agro-climatic zone, $L L=$ laminar length, $P L=$ petiole length, $N P P=$ number of pairs of pinnae, NPLtBP =number of leaflets for pinnae at the basis of the laminar, NPLtCP=number of leaflets for pinnae at the centre, NPLtTP=number of leaflets for pinnae at the top

Table 6: Mean fruit size variables by stand in agro-climatic zones

\begin{tabular}{|c|c|c|c|c|c|c|}
\hline \multicolumn{7}{|c|}{ Fruit size parameters } \\
\hline \multirow[t]{2}{*}{$\mathrm{ACZ}$} & \multicolumn{2}{|c|}{ Mean PeL (cm) } & \multicolumn{2}{|c|}{ Mean PoL (cm) } & \multicolumn{2}{|c|}{ Mean PoWi (mm) } \\
\hline & Fields & Fallows & Fields & Fallows & Fields & Fallows \\
\hline NS & $3.81 \pm 1.12^{\mathrm{a}}$ & $3.38 \pm 1.22^{\mathrm{bc}}$ & $20.94 \pm 3.86^{c}$ & $21.00 \pm 4.41^{c}$ & $17.88 \pm 7.98^{\mathrm{a}}$ & $18.24 \pm 2.11$ \\
\hline SS & $3.71 \pm 1.25^{\mathrm{a}}$ & $3.85 \pm 1.08^{a}$ & $21.78 \pm 5.23^{b}$ & $19.14 \pm 4.26^{d}$ & $16.47 \pm 3.18^{b}$ & $15.91 \pm 1.76^{6}$ \\
\hline$N G$ & $3.17 \pm 0.77^{c}$ & $3.61 \pm 1.10^{\mathrm{ab}}$ & $23.06 \pm 9.91^{\mathrm{a}}$ & $19.16 \pm 4.04^{d}$ & $16.49 \pm 1.42^{\mathrm{b}}$ & $15.88 \pm 1.55$ \\
\hline
\end{tabular}

For each variable, means with the same letter were not significantly different. ACZ =agro-climatic zone, NS=north Sudanian, SS=south Sudanian, $N G=$ North Guinean $P e L=$ pedicel length, $\mathrm{PoL}=$ pod length, $\mathrm{PoW}=$ pod wide, $\mathrm{PoWe}=$ pod weight, NS $/ \mathrm{Po}=$ number of seeds per pod, $\mathrm{SWe}=$ seed weight per pod

Table 7: Mean pod and seeds weight by stand in agro-climatic zones

\begin{tabular}{|c|c|c|c|c|c|c|}
\hline \multicolumn{7}{|c|}{ Pod and seed parameters } \\
\hline \multirow[t]{2}{*}{$\overline{A C Z}$} & \multicolumn{2}{|c|}{ Mean PoWe (g) } & \multicolumn{2}{|c|}{ Mean SWe/Po (g) } & \multicolumn{2}{|c|}{ Mean NS/Po } \\
\hline & Fields & Fallows & Fields & Fallows & Fields & Fallows \\
\hline NS & $13.45 \pm 3.55^{b}$ & $14.87 \pm 3.95^{\mathrm{a}}$ & $3.12 \pm 1.06^{c}$ & $3.49 \pm 0.99^{b}$ & $15 \pm 4^{c}$ & $16 \pm 3^{b}$ \\
\hline SS & $12.99 \pm 3.77^{b}$ & $11.63 \pm 3.36^{\mathrm{c}}$ & $3.60 \pm 1.13^{\mathrm{ab}}$ & $2.96 \pm 0.98^{c}$ & $17 \pm 3^{a}$ & $15 \pm 4^{c}$ \\
\hline$N G$ & $13.29 \pm 2.85^{b}$ & $10.28 \pm 3.16^{d}$ & $3.74 \pm 0.96^{a}$ & $2.99 \pm 0.88^{c}$ & $17 \pm 3^{a}$ & $15 \pm 4^{c}$ \\
\hline
\end{tabular}

For each variable, means with the same letter were not significantly different. $A C Z=$ agro-climatic zone, NS =north Sudanian, $S S=$ south $S$ udanian, $N G=$ North Guinean $P e L=$ pedicel length, $P o L=$ pod length, $P o W i=$ pod wide, PoWe $=$ pod weight, NS/Po=number of seeds per pod, $S W e=$ seed weight per pod

that the difference between sites was due to the combined effects of rainfall, temperature, soil types, tree distribution and land use type.

P. biglobosa fruit traits we observed were significantly lower than those reported by Olorunmaiye et al. (2011). These authors reported pod length ranged from 14.54 to $48.52 \mathrm{~cm}$ with an average of $24.72 \mathrm{~cm}$ against 4.7 to $35.5 \mathrm{~cm}$ with an average of $20.95 \mathrm{~cm}$ for this study; pod width ranged from
12.05 to $31.04 \mathrm{~mm}$ with an average of $23.23 \mathrm{~mm}$ against 5.22 to $27.81 \mathrm{~mm}$ with an average of $16.94 \mathrm{~mm}$ for this study; pod weight ranged from 53.09 to $224.2 \mathrm{~g}$ with an average of $157.25 \mathrm{~g}$ against 2.92 to $27.81 \mathrm{~g}$ with an average of $13.05 \mathrm{~g}$ for this study. According to Oyerinde et al. (2018), the variations in fruit and seed characteristics of $P$. biglobosa were consistent with the results reported for Irvingia gabonensis by Atangana et al. (2001), which stated that the high diversity of fruit among states could be due to climatic, edaphic and cultural factors. 
In Benin, Koura et al. (2013) observed a significant difference between four subpopulations of $P$. biglobosa with respect to leaf, fruit and seed variables. The means observed by these authors for variables such as pod length, number of seeds per pod, and pod weight were close to those we obtained in this study. However, it should be noted that, these authors did not explicitly identify the factors underlying the variations they observed, but they cited several other authors (Kouyaté, 2005; Sanou et al., 2006), which stated that, the existence of morphological variations at the level of subpopulations of a species can be explained by ecological and genetic variations. Koura et al. (2013) concluded that, a characterization of $P$. biglobosa subpopulations identified in their study was necessary on the climato-pedological and genetic levels. Beyond the sub-region, in Africa and Madagascar, Hopkins (1983) observed variation in leaves and leaflets of P. biglobosa along the latitudinal gradient. This trend of latitudinal variation was also observed for several aspects of V. paradoxa like morphological characters of leaves and fruits (Sanou, 2008), fat content (Davrieux \& Piombo, 2008), chemical composition of butter (Maranz et al., 2004; Davrieux et al., 2010).

Regarding the stand effect, a significant difference was observed between fields and fallows. For most of leaf and fruit variables, the means were higher in the fields compared to the fallows. This result suggests that trees benefit from the reduced competition with other plants in the fields and also from care brought to crops. Oyerinde et al. (2018) reported a possible effect of land use type on the difference between sites with respect to P. biglobosa fruit variables. For V. paradoxa (another parkland tree species), several authors have reported that human activities have a positive influence on fruit production and this positive effect is partly due to agricultural practices like reduction of tree density, plowing, weeding and crops fertilization, tree selection (Lamien et al., 2004; Okullo et al., 2004; Kelly et al., 2007; Bondé et al., 2013; Kelly et al., 2019). A significant effect of land use on fruit production has also been reported for Sclerocaya birrea (Shackleton et al., 2002) and for Lannea microcarpa (Haameyer et al., 2013). In contrast, land use was not found to significantly influence fruit production of Adansonia digitata and Bombax costatum (Ouédraogo et al., 2004; Schumann et al., 2010).

\section{CONCLUSIONS}

Findings of this study suggest that many $P$. biglobosa leaf and fruit variables are rather controlled by an endogenous factor that could be genetic. Other exogenous factors such as environment and management practices seem to also have a significant influence in the variation of these organs of $P$. biglobosa. The findings also confirm results of previous studies regarding the variation of morphological traits of forest tree species particularly those of agroforestry parklands in the terms of adaptation strategies and influencing forces. In developing a program for the domestication of P. biglobosa, theses aspects should be considered.

\section{ACKNOWLEDGEMENTS}

Authors are grateful to the Malian government for funding the Parkia project through the Competitive Fund for Research and Technological Innovation (CFRTI). We also appreciate and thank authorities and populations of study sites for allowing us to undertake the study on their field and fallow parcels and also for cooperating in field activities. We are also grateful to field technicians (Isaïe Dembélé, Younoussa Diarra and Mamadou Diabaté), who carried out the work of monitoring and data recording and to IRP/IFRA students (Adama B. Traoré and Aboubacar S. Dembélé), who worked on this aspect of the project's activities as part of their end of study dissertation for forestry engineering degree.

\section{REFERENCES}

Arbonnier, M. (2002). Arbres arbustes et lianes des zones sèches d'Afrique de l'Ouest. CIRAD-MNHN, $573 \mathrm{p}$.

Assogbadjo, A. E. (2006). Importance socio-économique et étude de la variabilité écologique, morphologique, génétique et biochimique du baobab (Adansonia digitata L.) au Bénin. Thèse de doctorat, Faculté Bio-Ingenieurs wetenschappen, Universiteit Gent, 213 p.

Atangana, A. R., Tchoundjeu, Z., Fondoun, J-M., Asaah, E., Ndoumbe, M., \& Leakey, R. R. B. (2001). Domestication of Irvingia gabonensis: Phenotypic variation in fruits and Kernels in two populations from Cameroon. Agroforestry Systems, 53(1), 55-64. https://doi. org/10.1023/A:1012293700774

Avana-Tientcheu, M. L. A., Keouna, S., Dongock Nguemo, D., \& Mouga Masdewel, B. (2019). Structure des peuplements et potentiel de domestication de Parkia biglobosa dans la région de Tandjilé-Ouest (Tchad). International Journal of Biological and Chemical Sciences, 13(1), 219-236. https://doi.org/10.4314/ijbcs.v13i1.19

Ayihouenou, E., Fandohan, A., Sode, I., Gouwakinnou, G., \& Djossa, B. (2016). Biogéographie du néré (Parkia biglobosa (Jack.) R. Br. ex. Don.) sous les conditions environnementales actuelles et futures au Bénin. Bulletin de la Recherche Agronomique du Bénin (BRAB). Numéro Spécial Agronomie, Société, Environnement and Sécurité Alimentaire.

Bamba, H., Korbo, A., Sanou, H., Ræbild, A., Kjær, E. D., \& Hansen, J. K. (2019). Genetic differentiation in leaf phenology among natural populations of Adansonia digitata L. follows climatic clines. Global Ecology and Conservation, 17, e00544. https://doi.org/10.1016/j. gecco.2019.e00544

Bationo, P., Zongo, J. D., Nanema, R. K., \& Traoré, E. R. (2008). Etude de la variation de quelques caractères morphologiques d'un échantillon de Sclerocarya birrea au Burkina Faso. International Journal of Biological and Chemical Sciences, 2, 549-562. https://doi.org/10.4314/ijbcs. v2i4.39765

Bondé, L., Ouédraogo, O., Traoré, S., Thiombiano, A., \& Boussim, J. I. (2013). Impact of environmental conditions on fruit production patterns of shea tree (Vitellaria paradoxa C.F.Gaertn) in West Africa. African Journal of Ecology, 1-10. https://doi.org/10.1111/aje.12621

Brown, A. H. D., \& Hardner, C. M. (2000). Sampling the gene pools of forest trees for ex situ conservation. In A. Young, D. Boshier \& T. Boyle (Eds.), Forest Conservation Genetics (pp. 185-196), CSRO, CABI Publishing.

Davrieux, F., \& Piombo, G. (2008). Variation of pattern in fatty acid and tocopherol in population of Mali and Uganda. Research periodic report for the INNOVKAR project presented at the Innovkar steering committee at Tamale (Ghana). 23 p.

Davrieux, F., Allal, F., Piombo, G., Kelly, B., Okullo, J. B., Thiam M., Diallo, O. B., \& Bouvet J-M. (2010). Near infrared spectroscopy for highthroughput characterization of shea tree (Vitellaria paradoxa) nut fat profiles. Journal of Agricultural and Food Chemistry, 58, 7811-7819. https://doi.org/10.1021/jf100409v

Dicko, A., Natta, A. K., Biaou, H. S. S., \& Akossou, A. (2019). Assessing morphological traits variation and fruit production of Lophira lanceolate (Ochnaceae) in Benin. American Journal of Plant Sciences, 10, 10481060. https://doi.org/10.4236/ajps.2019.106076 
Djekota, C., Diouf, D., Sane, S., Mbaye, M. S., \& Noba, K. (2014). Morphological characterization of Shea tree (Vitellaria paradoxa subsp. paradoxa) populations in the region of Mandoul in Chad. International Journal of Biodiversity and Conservation, 6(2), 184-193. https://doi.org/10.5897//JBC2013.0662

Fagui. (2015). Répertoire des espèces forestières des régions de Kayes, Koulikoro, Sikasso et Ségou. Mali, 339 p.

Freigoun, S. A. B., Raddad, E. Y. A., \& Elagib, T. Y. (2017). Provenance variation in seed morphological traits and early seedling growth of Balanites aegyptiaca Del. Sudan. Journal of Agricultural Research, 27, 93-108.

Glèlè Kakaï, R., Akpona, T. J. D., Assogbadjo, A. E., Gaoué, O. G., Chakeredza, S., Gnanglé, P. C., Mensah, G. A., \& Sinsin, B. (2011). Ecological adaptation of the shea butter tree (Vitellaria paradoxa C.F. Gaertn.) along Climatic Gradient in Bénin, West Africa. African Journal of Ecology, 49, 440-449. https://doi.org/10.1111/j.13652028.2011.01279.x

Goba, K. A. E., Kouonon, L. C., Koffi, K. G., Bony, B. S., Diomandé, I., \& Sié, R. S. (2019). Morphological Diversity within Pterocarpus erinaceus Poir. (Fabaceae), an overexploited species in the savannahs of Côte d'Ivoire. American Journal of Plant Sciences, 10(9), 1675-1688. https:// doi.org/10.4236/ajps.2019.109119

Gouwakinnou, N. G. (2011). Population ecology, uses and conservation of Sclerocarya birrea (A. Rich) Hocchst. (Anacardiaceae) in Benin, West Africa. Ph.D. Thesis, University of Abomey-Calavi, AbomeyCalavi, $176 \mathrm{pp}$

Gwali, S., Nakabonge, G., Okullo, J. B. L., Eilu, G., Nyeko, P., \& Vuzi, P. (2012). Morphological variation among Shea tree (Vitellaria paradoxa subsp. nilotica), ethnovarieties" in Uganda. Genetic Resources and Crops Evolution, 59, 1883-1898. https://doi.org/10.1007/s10722-012-9905-8

Haarmeyer, D. H., Schumann, K., Bernhardt-Römermann, M., Wittig, R., Thiombian, \& A., Hahn, K. (2013). Human impact on population structure and fruit production of the socio-economically important tree Lannea microcarpa in Burkina Faso. Agroforestry Systems, 87(6), 1363-1375. https://doi.org/10.1007/s10457-013-9644-7

Hopkins, H. C. (1983). The taxonomy, reproductive biology and economic potential of Parkia biglobosa (Leguminosae: Mimosoideae) in Africa and Madagascar. Botanical Journal of the Linnean Society, 87, 135167. https://doi.org/10.1111/j.1095-8339.1983.tb00987.x

Houètchégnon, T., Gbèmavo, D. S. J., \& Ouinsavi, C. (2015). Morphological variability of Prosopis Africana (Guill., Perrot. Et Rich.) Taub in Benin, West Africa. American Journal of Plant Sciences, 6, 1069-1079. https://doi.org/10.4236/ajps.2015.67111

Ikabanga, D. U., Stévart, T., Koffi, K.G., Monthé, K. F. S., Nzigo-Doubindou, E. C., Dauby, G., Souza, A., M'Batchi, B., \& Hardy, O. J. (2017). Combining morphology and population genetic analysis uncover species delimitation in the widespread African tree genus. Santiria Phytotaxa, 321(2), 166-180. https://doi.org/10.11646/phytotaxa.321.2.2

Johnson, B. N., Marie Luce, A., Adjonou, Q. K., Segla, K. N., Kokutse, A. D., \& Kokou, K. (2020). Morphological Variability of Pterocarpus erinaceus Poir. in Togo. International Journal of Forestry Research, 2020. 4878169. https://doi.org/10.1155/2020/4878169

Kelly, B. A., Gourlet-Fleury, S., \& Bouvet J-M. (2007). Impact of Agroforestry Practices on the Flowering Phenology of Vitellari paradoxa in parklands in Southern Mali. Agroforestry Systems, 7, 67-75. https:// doi.org/10.1007/s10457-007-9074-5

Kelly, B. A., \& Senou, O. (2017). Variation of leaf and fruit characteristics of Vitellaria paradoxa (shea tree) according to agronomical performance along south-north climatic gradient in Mali. African Journal of Plant Science, 11(5), 142 - 150. https://doi.org/10.5897/AJPS2017.1536

Kelly, B. A., Poudyal, M., \& Bouvet J-M. (2019). Impact of land use and land use history on fruits production of Vitellaria paradoxa (Shea tree) according to agroclimatic zones in Mali (West Africa). Current Botany, 10, 1-7. https://doi.org/10.25081/cb.2019.v10.3835

Kouonon, L. C., Koffi, K. G., Adjoumani, K., Mobio, A. D., \& Goba, K. A. (2020). Caractérisation phénotypique du néré (Parkia biglobosa (Jacq.) R. Br. ex G. Don, Fabaceae) dans trois types de savane de Côte d'Ivoire. International Journal of Biological and Chemical Sciences, 14(2), 555-569. https://doi.org/10.4314/ijbcs.v14i2.20

Koura, K., Mbaide, Y., \& Ganglo, J. C. (2013). Caractéristiques phénotypique et structurale de la population de Parkia biglobosa (Jacq.) R. Br. du Nord-Bénin. International Journal of Biology and Chemistry Sciences, 7(6), 2409-2425. https://doi.org/10.4314/ijbcs.v7i6.19
Kouyaté, A. M. (2005). Aspects ethnobotaniques et étude de la variabilité morphologique, biochimique et phénologique de Detarium microcarpum guill. \& perr. Rapport de recherche, IER, Mali.

Kouyaté, A. M., Decaluwé, E., Guindo, F., Diawara, H., Diarra, I., N'Diayé, I., \& Van Damme, P. (2011). Variabilité morphologique du baobab (Adansonia digitata L.) au Mali. Fruits, 66, 247-255. https:// doi.org/10.1051/fruits/2011032

Lamien, N., Ouédrago, S. J., Diallo, O. B., \& Guinko, S. (2004). Productivité fruitière du karité (Vitellaria paradoxa Gaertn. C.F., Sapotaceae) dans les parcs agroforestiers traditionnels au Burkina Faso. Fruits, 59, 423-429. https://doi.org/10.1051/fruits:2005004

Lankoande, B., Ouédraogo, A., Kouyaté, A. M., Boussim, I. J., \& Lykke, A. M. (2020). Production and morphological traits of Lophira lanceolata fruits in natural stands. Forests, Trees and Livelihoods, 29(3), 176- 186 https://doi.org/10.1080/14728028.2020.1791261

Lompo, D., Vinceti, B., Gaisberger, H., Konrad, H., Duminil, J., Ouedraogo, M., Sina, S., \& Geburek, T. (2017). Genetic conservation in Parkia biglobosa (Fabaceae: Mimosoideae)-what do we know? Silvae Genetica, 66(1), 1-8. https://doi.org/10.1515/sg-2017-0001

Maranz, S., Wiesman, Z., Bisgaard, J., \& Bianchi, G. (2004). Germplasm resources of Vitellaria paradoxa based on variations in fat composition across the species distribution range. Agroforestry Systems, 60, 71-76. https://doi.org/10.1023/B: AGFO.0000009406.19593.90

Nyarko, G., Mahunu, G. K., Chimsah, F. A., Yidana, J. A., Abubakari, A. H., Abagale, F. K., Quainoo, A., \& Poudyal, M. (2012). Leaf and fruit characteristics of Shea (Vitellaria paradoxa) in Northern Ghana. Research in Plant Biology, 2(3), 38-45.

Okullo, J-B. L., Hall, J. B., \& Obua, J. (2004). Leafing, flowering and fruiting of Vitellaria paradoxa subsp. nilotica in savannah parklands in Uganda. Agroforestry Systems, 60, 77-91. https://doi. org/10.1023/B: AGFO.0000009407.63892.99

Olorunmaiye, K. S., Fatoba, P. O., Adeyemi, O. C., \& Olorunmaiye, P. M. (2011). Fruit and seed characteristics among selected Parkia biglobosa (JACQ) G. Don. Population. Agriculture and Biology Journal of North America, 2(2), 244-249. https://doi.org/10.5251/abjna.2011.2.2.244.249

Ouédraogo, A. S. (1995). Parkia biglobosa (Leguminosae) en Afrique de I'Ouest: Biosystématique et Amélioration. Thèse de I'Université Agronomique de Wageningen, 205 pp.

Ouédraogo, A.S. (1986). Essai comparatif de provenances d'Acacia albida à Gonsé, Burkina Faso. Semences Forets-Développement, 27-32.

Ouédraogo, I., Nacoulma, B. M. I., Ouédraogo, O., Hahn, K., Thiombiano, A. (2004). Productivité et valeur économique des calices de Bombax costatum Pellegr. \& Vuillet en zone soudanienne du Burkina Faso. Bois et Forêts des Tropiques, 319, 31-41. https://doi.org/10.19182/ bft2014.319.a20550

Ouinsavi, C., \& Sokpon, N. (2010). Morphological variation and ecological structure of Iroko (Milicia excelsa Welw. C.C. Berg) populations across different biogeographical zones in Benin. International Journal of Forestry Research, 2010, 658396. https://doi.org/10.1155/10.658396

Ouoba, L. I. I., Rechinger, K. B., Diawara, B., Traoré, A. S., \& Kakobsen, M. (2003). Degradation of proteins during the fermentation of African locust bean (Parkia biglobosa) by strains of Bacillus subtilis and Bacillus pumilus for production of Soumbala. Journal of Applied Microbiology, 94(3), 396-402. https://doi.org/10.1046/j.13652672.2003.01845.x

Oyerinde, O.V., Olusola, J. A., \& Adebo, A. A. (2018). Variation in morphometric traits of trees, pods and seeds of Parkia biglobosa (Jacq) G. in southwestern Nigeria. International Journal of Conservation Science, 9(1), 185-192.

PDESC. (2017). Programme de Développement Economique Social et Culturel 2017-2021. Commune rurale de Diou.

PDESC. (2019). Programme de Développement Economique Social et Culturel 2018-2022. Commune rurale de Somasso et commune rurale de Zanzoni.

Ræbild, A., Graudal, L., \& Ouédraogo, L. G. (2003). Evaluation of a species and provenances trial of Acacia nilotica, A.seyal and A. tortilis at Gonsé, Burkina Faso. Trial no. 10 in the arid zone series. Results and Documentation No. 9. CNSF, Danida Forest Seed Centre, FAO, 72 p.

Sacandé, M., Sanogo, S., \& Beentje, H. (2016). Guide d'Identification des Arbres du Mali. Royal Botanic Gardens, Kew, Richmond, Surrey, $\mathrm{TW}_{93} \mathrm{AB}$, Royaume-Uni.www.kew.org

Samim, S., Sood, S., Singh, A., Verma, A., \& Kaur, A. (2018). Morphological Characterization of Okra [Abelmoschus esculentus (L.) Moench]. 
International Journal of Current Microbiology and Applied Sciences, 7, 2011-2019. https://doi.org/10.4172/2329-8863.1000197

Sanou, H. (2008). Domestication and pre-breeding of shea tree: characterisation, mobilisation of local varieties by a multitrait and participative approach and horticultural research. Research periodic report for the INNOVKAR Project.

Sanou, H., Picard, N., Lovett, P. N., Dembélé, M., Korbo, A., Diarisso, D., \& Bouvet, J-M. (2006). Phenotypic variation of agromorphological traits of the shea tree, Vitellaria paradoxa C.F. Gaertn., in Mali. Genetic Ressources and Crop Evolution, 53, 145-161. https://doi.org/10.1007/ s10722-004-1809-9

Schumann, K., Wittig, R., Thiombiano, A., Becker, U., \& Hahn, K. (2010). Impact of land-use type and bark- and leaf-harvesting on population structure and fruit production of the baobab tree (Adansonia digitate L.) in a semi-arid savanna. West Africa. Forest Ecology and Management, 260, 2035-2044. https://doi.org/10.1016/j. foreco.2010.09.009

Shackleton, C. M., Botha, J., Emanuel, P. L., \& Ndlovu, S. (2002). Inventory of marula (Sclerocarya birrea subsp. caffra) stocks and fruit yields in communal and protected areas of the Bushbuckridge Lowveld, Limpopo Province. Report to U K DFID Forestry Research Programme Project No R7795. Rhodes University, Grahamstown 6140, South Africa.

Ugese, F. D., Baiyeri, P. K., \& Mbah, B. N. (2010). Agroecological variation in the fruits and nuts of Shea butter tree (Vitellaria paradoxa C. F Gaertn.) in Nigeria. Agroforestry Systems, 79, 201-211. https://doi. org/10.1007/s10457-009-9261-7

Zahidi, A., Bani-Aameur, F., \& El Mousadik, A. (2013). Variability in leaf size and shape in three natural populations of Argania spinosa (L.) Skeels. International Journal of Current Research and Academic, 1, 13-25. 